\title{
Effect of prepartum maternal energy density on the growth performance, immunity, and antioxidation capability of neonatal calves
}

\author{
F. Gao, ${ }^{\star 1,2}$ Y.-C. Liu, ${ }^{1}$ Z.-H. Zhang, ${ }^{\star}$ C.-Z. Zhang, ${ }^{\star}$ H.-W. Su,‡ and S.-L. Li ${ }^{2}$ \\ ${ }^{*}$ College of Animal Science, and \\ †College of Life Science, Inner Mongolia Agricultural University, Hohhot, 010018, China \\ $\ddagger$ College of Animal Science and Technology, China Agricultural University, State Key Laboratory of Animal Nutrition, Beijing, 100193, China
}

\begin{abstract}
This study investigated the effect of prepartum diets differing in energy density on growth performance, immunity, and antioxidation capability of neonatal calves. Thirty Holstein dairy cows were allocated at random into 3 groups: low energy group [L; net energy of lactation $\left(\mathrm{NE}_{\mathrm{L}}\right)=5.25 \mathrm{MJ} / \mathrm{kg}$ of dry matter $\left.(\mathrm{DM})\right]$; medium energy group $\left(\mathrm{M} ; \mathrm{NE}_{\mathrm{L}}=5.88 \mathrm{MJ} / \mathrm{kg}\right.$ of $\left.\mathrm{DM}\right)$; and high energy group $\left(\mathrm{H} ; \mathrm{NE}_{\mathrm{L}}=6.48 \mathrm{MJ} / \mathrm{kg}\right.$ of $\left.\mathrm{DM}\right)$ at $\mathrm{d} 21$ prepartum. Plasma was sampled for analysis of glucose, total protein, $\beta$-hydroxybutyrate, and nonesterified fatty acids at 21,14 , and $7 \mathrm{~d}$ before parturition. After calving, birth weight and measurements of the calves in each group were recorded, and blood samples were collected for analysis of CD4, CD8, CD21, IL-2, IL-4, IL-6, total antioxidant capacity, superoxide dismutase, glutathione peroxidase, and maleic dialdehyde. The results indicated that although maternal weight did not differ among $\mathrm{L}, \mathrm{M}$, and $\mathrm{H}$ groups at 21,14 , and $7 \mathrm{~d}$ before parturition, the concentrations of glucose and $\beta$-hydroxybutyrate at 14 and $7 \mathrm{~d}$ in the $\mathrm{L}$ group were decreased compared with that in the $\mathrm{H}$ group. In addition, nonesterified fatty acids concentrations increased significantly in the L group at 14 and $7 \mathrm{~d}$ before parturition compared with that in the $\mathrm{M}$ and $\mathrm{H}$ groups. Birth weight, body height, body length, abdominal circumference, thoracic girth, umbilical girth, and levels of CD4, CD4:CD8, IL-2, IL-4, total antioxidant capacity, and superoxide dismutase were decreased in calves of the $\mathrm{L}$ group compared with those of the $\mathrm{H}$ group. For the M group, CD4, CD4:CD8, and superoxide dismutase were decreased; and in the L group glutathione peroxidase and maleic dialdehyde levels were significantly increased compared with those of the
\end{abstract}

\footnotetext{
Received October 25, 2011.

Accepted March 26, 2012.

${ }^{1}$ These authors contributed equally to the research.

${ }^{2}$ Corresponding authors: gaofeng1994@sina.com/gaofeng1994@ yahoo.com.cn and lisheng0677@163.com
}

$\mathrm{H}$ group. Reducing the maternal energy density during the last $21 \mathrm{~d}$ before parturition had a negative effect on growth and development, immunity, and antioxidation capability of neonatal calves.

Key words: prepartum energy density, growth performance, immunity, antioxidation

\section{INTRODUCTION}

The transition period, from $21 \mathrm{~d}$ before to $21 \mathrm{~d}$ after parturition, is critically important to the health, production, and profitability of dairy cows (Drackley, 1999). Epidemiological data and field observations suggest that, as a result of negative energy balance, the combined incidence rate for dystocia (Gaafar et al., 2011), milk fever (Grétar, 2001; Mulligan et al., 2006), retained placenta (Houe et al., 2001), metritis (Ghavi Hossein-Zadeh and Ardalan, 2011), ketosis (Bateman et al., 2005), displaced abomasum (Van Winden et al., 2002), fatty liver (Reynolds et al., 2004; Ingvartsen, 2006), and lameness (Kimura et al., 2006) means that only $50 \%$ of all cows calve without health problems (Ferguson, 2001). Some researchers have indicated that higher energy concentration of the diet precalving could improve voluntary intake, increase BW gain (VandeHaar et al., 1999; Dewhurst et al., 2000), and reduce the mobilization of adipose tissue and plasma NEFA concentrations (Ingvartsen and Andersen, 2000; Hayirli et al., 2002), which would improve the maternal regulation of physiological responses and enhance productive performance during the transition period (Contreras et al., 2004). In contrast, others believe that the low energy density of diets during the transition period is associated with improved DMI, energy intake, and energy balance (Douglas et al., 1998; Holcomb et al., 2001; Rabelo et al., 2003). Although still debatable, both high (McMillen et al., 2001) and low (Osgerby et al., 2002; Quigley et al., 2008) energy diets prepartum could have negative effects on fetal and neonatal animal growth.

The growth and development of the fetus is a specific physiological process (Gao et al., 2008). Fetal develop- 
ment and growth rate depend on maternal nutrition, which provides amino acids, glucose, and NEFA to the fetus by blood cycling (Zhu et al., 2007; Zhang et al., 2010). A few studies have demonstrated that maternal under- and overnutrition during prepartum could not only result in perturbations to fetal development (Louey et al., 2000; Micke et al., 2010) and alter the ontogeny of fetal organ growth and development (Gao et al., 2009), but also lead to modifications of the postnatal growth pathway, metabolism, and body composition of the offspring (McMillen et al., 2001; Redmer et al., 2004). However, less attention has been paid to the modification of growth and physiology in the fetus and in neonatal calves affected by different maternal energy levels during transition. The health of neonatal calves is important, and researchers are now focusing on the developmental condition of fetus and neonatal calves during the transition period. Therefore, the objective of this study was to investigate the effect of prepartum diet energy density on the growth performance, immunity, and antioxidation capability of neonatal calves.

\section{MATERIALS AND METHODS}

\section{Animals and Treatments}

According to expected calving date, BW, and BCS, 30 multiparous Holstein dairy cows were allocated at random into 3 groups differing in energy density of the diet (Table 1) fed for $21 \mathrm{~d}$ prepartum: low energy group $\left(\mathbf{L} ; \mathrm{NE}_{\mathrm{L}}=5.25 \mathrm{MJ} / \mathrm{kg}\right.$ of $\left.\mathrm{DM}\right) ;$ medium energy group $\left(\mathbf{M} ; \mathrm{NE}_{\mathrm{L}}=5.88 \mathrm{MJ} / \mathrm{kg} \mathrm{DM}\right)$, and high energy group $\left(\mathbf{H} ; \mathrm{NE}_{\mathrm{L}}=6.48 \mathrm{MJ} / \mathrm{kg}\right.$ of DM). The cows were housed in individual tie stalls, fed at 0500, 1200, and $1900 \mathrm{~h}$ daily, and had free access to water. Live weights of cows in each group were measured and blood was sampled from the jugular vein into evacuated tubes containing lithium on d 21, 14, and 7 before parturition, at 0730 $\mathrm{h}$, before feeding. The plasma samples were stored at $-70^{\circ} \mathrm{C}$ for analyzing of glucose $(\mathbf{G l u})$, total protein (TP), BHBA, and NEFA.

After calving, 10 calves in each group were selected and birth weight and measurements of the calves were recorded. Two-milliliter blood samples were collected in evacuated tubes containing lithium as anticoagulant to analyze the expression of CD4, CD8, and CD21. Another sample of $20 \mathrm{~mL}$ of blood was centrifuged immediately at $4,500 \times g$ for $10 \mathrm{~min}$, and the plasma was stored at $-70^{\circ} \mathrm{C}$ for analysis of IL-2, IL-4, IL-6, total antioxidant capacity (T-AOC), superoxide dismutase (SOD), glutathione peroxidase (GSH-Px), and maleic dialdehyde (MDA).

\section{Detection of GIU, TP, BHBA, and NEFA Concentrations in Cows}

Commercial kits were purchased for analysis of Glu (050520, Prodia Diagnostics, Botzingen Germany), TP (20110422, Kehua Biological Corp., Shanghai, China), BHBA (BHB0210, Jingyuan Medical Apparatus and Instruments Corp., Shanghai, China) and NEFA (095207, Hydrops Medical Corp., Tokyo, Japan) by Hitachi automatic biochemical analyzer (7600-020, Hitachi, Tokyo, Japan).

\section{Monoclonal Antibody and Flow Cytometric Analyses}

A $300-\mu \mathrm{L}$ sample from $2 \mathrm{~mL}$ of blood of each calf was taken and added to $9 \mathrm{~mL}$ of triple-distilled water;

Table 1. Ingredient and nutrient levels of prepartum diets

\begin{tabular}{|c|c|c|c|}
\hline \multirow[b]{2}{*}{ Item } & \multicolumn{3}{|c|}{ Group $^{1}$} \\
\hline & $\mathrm{L}$ & M & $\mathrm{H}$ \\
\hline \multicolumn{4}{|l|}{ Ingredient, $\%$ of DM } \\
\hline Corn straw & 36.5 & 17 & 0 \\
\hline Corn silage & 0 & 19.9 & 36.5 \\
\hline Chinese wildrye & 26.9 & 24.9 & 22.9 \\
\hline Alfalfa hay & 16.1 & 7.5 & 0 \\
\hline Ground corn & 8.4 & 15.7 & 23.2 \\
\hline Wheat gluten & 2.2 & 2.4 & 2.8 \\
\hline Soybean meal & 2.5 & 3.1 & 2.8 \\
\hline Cottonseed meal & 2.6 & 3 & 2.4 \\
\hline Rapeseed meal & 2 & 3 & 2.4 \\
\hline Distillers dried grains & 1.5 & 2.2 & 2.4 \\
\hline \multicolumn{4}{|l|}{ with solubles } \\
\hline $\mathrm{ESB}^{2}$ & 0 & 0 & 3.2 \\
\hline Premix $^{3}$ & 1.2 & 1.3 & 1.4 \\
\hline Total & 100 & 100 & 100 \\
\hline \multicolumn{4}{|l|}{ Nutrient composition } \\
\hline $\mathrm{NE}_{\mathrm{L}},{ }^{4} \mathrm{MJ} / \mathrm{kg}$ & 5.25 & 5.88 & 6.48 \\
\hline $\mathrm{CP}, \%$ & 13 & 13.14 & 13.06 \\
\hline Ether extract, \% & 2.35 & 3.13 & 3.44 \\
\hline NDF, $\%$ & 56.25 & 49.88 & 43.5 \\
\hline $\mathrm{ADF}, \%$ & 32.52 & 27.91 & 22.94 \\
\hline $\mathrm{NFC}^{5}, \%$ & 20.63 & 26.92 & 33.68 \\
\hline Ash, $\%$ & 8.77 & 7.34 & 6.32 \\
\hline $\mathrm{Ca}, \%$ & 0.75 & 0.7 & 0.63 \\
\hline $\mathrm{P}, \%$ & 0.33 & 0.37 & 0.39 \\
\hline
\end{tabular}

${ }^{1} \mathrm{~L}=$ low energy $\left(\mathrm{NE}_{\mathrm{L}}=5.25 \mathrm{MJ} / \mathrm{kg}\right.$ of $\left.\mathrm{DM}\right) ; \mathrm{M}=$ medium energy $\left(\mathrm{NE}_{\mathrm{L}}=5.88 \mathrm{MJ} / \mathrm{kg}\right.$ of $\left.\mathrm{DM}\right) ; \mathrm{H}=$ high energy $\left(\mathrm{NE}_{\mathrm{L}}=6.48 \mathrm{MJ} / \mathrm{kg}\right.$ of $\mathrm{DM})$.

${ }^{2}$ ESB (extruded full-fat soybean) contained $91.0 \% \mathrm{DM}, 38.7 \% \mathrm{CP}$, $20.6 \%$ ether extract, $23.6 \%$ NDF, $12.4 \%$ ADF, $6.20 \%$ ash, $0.26 \% \mathrm{Ca}$, $0.61 \% \mathrm{P}$ (DM basis).

${ }^{3}$ Premix contained (per $\mathrm{kg}$ of premix): 440,000 IU of vitamin A, $110,000 \mathrm{IU}$ of vitamin $\mathrm{D}_{3}, 4,000 \mathrm{IU}$ of vitamin $\mathrm{E}, 400 \mathrm{mg}$ of niacin, 152 $\mathrm{g}$ of Ca, $41 \mathrm{~g}$ of P, $750 \mathrm{mg}$ of $\mathrm{Cu}, 1,140 \mathrm{mg}$ of Mn, 2,970 $\mathrm{mg}$ of Zn, 30 $\mathrm{mg}$ of I, $36 \mathrm{mg}$ of Se, and $24 \mathrm{mg}$ of Co.

${ }^{4} \mathrm{NE}_{\mathrm{L}}$ was calculated based on NRC (2001).

${ }^{5} \mathrm{NFC}=100-(\% \mathrm{NDF}+\% \mathrm{CP}+\%$ fat $+\%$ ash $)$ according to NRC (2001). 
then erythrocyte-depleted lymphocytes were suspended in PBS and then centrifuged at 1,700 $\times g$ for $5 \mathrm{~min}$ at $4^{\circ} \mathrm{C}$. Lymphocytes $\left(2 \times 10^{6}\right)$ were prepared and washed once with PBS, pH 7.4, containing $0.1 \%$ BSA. The lymphocytes were then stained with fluorescein isothiocyanate (FITC)-conjugated mouse anti-bovine CD4 monoclonal antibodies (mAb; MCA1653F, IgG2a), phycoerythrin (PE)-conjugated mouse anti-bovine CD8 mAb (MCA837PE, IgG2a), and FITC-conjugated mouse anti bovine CD21 mAb (MCA1424F, IgG1). All antibodies were purchased from AbD Serotec (Raleigh, NC); FITC- or PE-conjugated isotype-matched antibodies were purchased as controls (4ABIO, Beijing, China), including mouse IgG2a-FITC (FMCF002-100), mouse IgG2a-PE (FMCP002-100), and mouse IgG1FITC (FMCF001-100). Cells were incubated for $30 \mathrm{~min}$ at $4^{\circ} \mathrm{C}$. After washing, the cells were resuspended in staining buffer and analyzed on a flow cytometer (FACSCalibur, Becton Dickinson, Franklin Lakes, NJ), and data were analyzed with CellQuest software (Becton Dickinson).

\section{Detection of IL-2, IL-4, and IL-6 in Neonatal Calves by RIA}

The concentrations of IL-2 (KY-007), IL-4 (KY010), and IL-6 (KY-012) were determined using RIA kits (Puerweiye Biological Technology, Beijing, China). Intra- and interassay CV were 6.6 and $12.7 \%, 7.6$ and $14.3 \%$, and 6.9 and $13.2 \%$ o for IL-2, IL-4, and IL-6, respectively.

\section{Detection of T-AOC, GSH-PX, SOD, and MDA Concentrations in Neonatal Calves}

Concentrations of GSH-Px (A005), SOD (A001-1), and MDA (A003-1) were analyzed using commercial kits (NJJCBIO, Nanjing, China). Concentrations were determined using colorimetric methods with a spectrophotometer (WFJ 2100, UNIC Instrument Co. Ltd., Shanghai, China) according to the procedures of Paglia and Valentine (1967), Panchenko et al. (1975), and Placer et al. (1966), respectively. Total antioxidant capacity was examined by commercial kit (A015; NJJCBIO), and a spectrometric method was applied to evaluate T-AOC. In the reaction mixture, ferric ion was reduced by antioxidant reducing agents and blue complex $\mathrm{Fe}^{2+}$-2,4,6-tri (2-pyridyl)-s-triazine (TPTZ) was produced; absorbance was measured at $520 \mathrm{~nm}$. One unit of T-AOC was defined as the amount that increased the absorbance by 0.01 at $37^{\circ} \mathrm{C}$, and was expressed as units per milliliter in plasma.

\section{Statistical Analysis}

All data were assessed according to the general linear model (ANOVA) procedure of the SAS Institute Inc. (Cary, NC). Duncan's test was used to identify significant differences between mean values. Data were presented as means \pm standard error, and significance was declared at $P<0.05$ and $P<0.01$.

\section{RESULTS}

\section{Effect of Prepartum Dietary Energy Density on BW and Concentrations of GIU, NEFA, BHBA, and TP in Plasma}

No significant difference in cow BW was observed among $\mathrm{L}, \mathrm{M}$, and $\mathrm{H}$ groups at 21,14 , and $7 \mathrm{~d}$ before parturition $(P>0.05)$, although $\mathrm{BW}$ in $\mathrm{L}$ and $\mathrm{M}$ groups tended to decrease compared with that of $\mathrm{H}$ group (Table 2). Additionally, the concentrations of Glu and BHBA in the L group were lower at $14 \mathrm{~d}(P<$ $0.05)$ and $7 \mathrm{~d}(P<0.01)$ before parturition compared with those of the $\mathrm{H}$ group, but NEFA were increased significantly in the L group at 14 and $7 \mathrm{~d}$ before parturition compared with that in the $\mathrm{M}$ and $\mathrm{H}$ groups $(P$ $<0.01)$. The results indicated that although energy density during prepartum greatly affected metabolic responses of dairy cows, it had no significant influence on the BW of cows as pregnancy progressed.

\section{Effects of Prepartum Dietary Energy Density on Weights and Measurements in Neonatal Calves}

The weights and measurements of neonatal calves in the H, M, and L groups tended to decrease linearly with decreasing energy density (Table 3 ). Calf weight $(P<0.01)$, body height $(P<0.01)$, body length $(P<$ $0.05)$, thoracic girth $(P<0.01)$, and umbilical girth $(P<0.05)$ in the $\mathrm{L}$ group were reduced significantly compared with those of the $\mathrm{H}$ group, demonstrating that weight and measurements in neonatal calves were influenced by maternal energy density in the last $21 \mathrm{~d}$ of pregnancy.

\section{Effects of Prepartum Dietary Energy Density on Expression of CD4, CD8, CD21, and CD4:CD8 in Lymphocytes of Neonatal Calves}

The CD4 expression of lymphocytes and CD4:CD8 were significantly lower in neonatal calves of $\mathrm{L}(P<$ $0.01)$ and $\mathrm{M}(P<0.05)$ groups than in the $\mathrm{H}$ group (Table 4; Figure 1). Expression of CD8 and CD21 did not differ significantly $(P>0.05)$ among groups (Fig- 
Table 2. Effects of prepartum maternal energy density on BW and concentrations of glucose (Glu), NEFA, $\mathrm{BHBA}$, and total protein (TP) in plasma of cows

\begin{tabular}{|c|c|c|c|}
\hline \multirow[b]{2}{*}{${\text { Item } / \text { group }^{1}}^{1}$} & \multicolumn{3}{|c|}{ Prepartum } \\
\hline & d 21 & d 14 & d 7 \\
\hline \multicolumn{4}{|l|}{$\mathrm{BW}, \mathrm{kg}$} \\
\hline $\mathrm{H}(\mathrm{n}=10)$ & $685.34 \pm 29.80^{\mathrm{a}}$ & $690.40 \pm 36.15^{\mathrm{a}}$ & $700.99 \pm 44.69^{\mathrm{a}}$ \\
\hline $\mathrm{M}(\mathrm{n}=10)$ & $695.07 \pm 49.52^{\mathrm{a}}$ & $692.06 \pm 49.17^{\mathrm{a}}$ & $689.40 \pm 52.34^{\mathrm{a}}$ \\
\hline $\mathrm{L}(\mathrm{n}=10)$ & $693.34 \pm 56.21^{\mathrm{a}}$ & $692.89 \pm 51.17^{\mathrm{a}}$ & $688.50 \pm 52.49^{\mathrm{a}}$ \\
\hline \multicolumn{4}{|l|}{ Glu, mmol/L } \\
\hline $\mathrm{H}(\mathrm{n}=10)$ & $3.52 \pm 0.29^{\mathrm{a}}$ & $3.90 \pm 0.12^{\mathrm{ac}}$ & $3.86 \pm 0.23^{\mathrm{a}}$ \\
\hline $\mathrm{M}(\mathrm{n}=10)$ & $3.53 \pm 0.31^{\mathrm{a}}$ & $3.74 \pm 0.17^{\mathrm{bcd}}$ & $3.65 \pm 0.20^{\mathrm{ab}}$ \\
\hline $\mathrm{L}(\mathrm{n}=10)$ & $3.58 \pm 0.26^{\mathrm{a}}$ & $3.63 \pm 0.16^{\mathrm{bd}}$ & $3.50 \pm 0.23^{\mathrm{b}}$ \\
\hline \multicolumn{4}{|l|}{ NEFA, $\mu \mathrm{Eq} / \mathrm{L}$} \\
\hline $\mathrm{H}(\mathrm{n}=10)$ & $133.05 \pm 18.52^{\mathrm{a}}$ & $119.71 \pm 23.60^{\mathrm{d}}$ & $146.06 \pm 52.22^{\mathrm{d}}$ \\
\hline $\mathrm{M}(\mathrm{n}=10)$ & $137.62 \pm 40.78^{\mathrm{a}}$ & $156.00 \pm 49.87^{\mathrm{d}}$ & $183.66 \pm 56.38^{\mathrm{d}}$ \\
\hline $\mathrm{L}(\mathrm{n}=10)$ & $136.42 \pm 29.19^{\mathrm{a}}$ & $305.21 \pm 95.99^{\mathrm{bd}}$ & $366.50 \pm 69.06^{\mathrm{c}}$ \\
\hline \multicolumn{4}{|c|}{$\mathrm{BHBA}, \mathrm{mmol} / \mathrm{L}$} \\
\hline $\mathrm{H}(\mathrm{n}=10)$ & $0.52 \pm 0.08^{\mathrm{a}}$ & $0.66 \pm 0.16^{\mathrm{ac}}$ & $0.61 \pm 0.16^{\mathrm{a}}$ \\
\hline $\mathrm{M}(\mathrm{n}=10)$ & $0.52 \pm 0.13^{\mathrm{a}}$ & $0.61 \pm 0.14^{\mathrm{acd}}$ & $0.62 \pm 0.12^{\mathrm{a}}$ \\
\hline $\mathrm{L}(\mathrm{n}=10)$ & $0.46 \pm 0.07^{\mathrm{a}}$ & $0.47 \pm 0.10^{\mathrm{bd}}$ & $0.47 \pm 0.08^{\mathrm{b}}$ \\
\hline \multicolumn{4}{|l|}{$\mathrm{TP}, \mathrm{g} / \mathrm{L}$} \\
\hline $\mathrm{H}(\mathrm{n}=10)$ & $77.83 \pm 5.74^{\mathrm{a}}$ & $75.53 \pm 6.88^{\mathrm{a}}$ & $74.56 \pm 5.98^{\mathrm{a}}$ \\
\hline $\mathrm{M}(\mathrm{n}=10)$ & $79.11 \pm 5.91^{\mathrm{a}}$ & $75.75 \pm 5.88^{\mathrm{a}}$ & $75.43 \pm 8.34^{\mathrm{a}}$ \\
\hline $\mathrm{L}(\mathrm{n}=10)$ & $77.49 \pm 4.73^{\mathrm{a}}$ & $75.53 \pm 3.26^{\mathrm{a}}$ & $72.04 \pm 7.48^{\mathrm{a}}$ \\
\hline
\end{tabular}

${ }^{\mathrm{a}-\mathrm{d}}$ Means in the same row without a common superscript differ (a,b: $\left.P>0.05 ; \mathrm{c}, \mathrm{d}: P<0.01\right)$. Means in rows with common superscripts do not differ $(P>0.05)$.

${ }^{1} \mathrm{~L}=$ low energy $\left(\mathrm{NE}_{\mathrm{L}}=5.25 \mathrm{MJ} / \mathrm{kg}\right.$ of $\left.\mathrm{DM}\right) ; \mathrm{M}=$ medium energy $\left(\mathrm{NE}_{\mathrm{L}}=5.88 \mathrm{MJ} / \mathrm{kg}\right.$ of $\left.\mathrm{DM}\right) ; \mathrm{H}=$ high energy $\left(\mathrm{NE}_{\mathrm{L}}=6.48 \mathrm{MJ} / \mathrm{kg}\right.$ of $\left.\mathrm{DM}\right)$.

ure 1). These results indicate that expression of CD4 of lymphocytes in neonatal calves was highly sensitive to maternal energy density during the last $21 \mathrm{~d}$ of pregnancy.

\section{Effects of Prepartum Dietary Energy Density on IL-2, IL-4, and IL-6 in Plasma of Neonatal Calves}

Effects of prepartum maternal energy density on IL-2, IL-4, and IL-6 in neonatal calves are presented in Table 5. Concentrations of IL-2 and IL-4 in neonatal calves were strongly influenced by maternal energy density at the last $21 \mathrm{~d}$ of pregnancy such that concentrations of IL-2 $(P<0.05)$ and IL-4 $(P<0.01)$ were much lower in the $\mathrm{L}$ group than in the $\mathrm{H}$ group. Concentrations of IL-6 did not differ among groups.

\section{Effects of Prepartum Dietary Energy Density on the Antioxidation Capability in Neonatal Calves}

Effects of prepartum energy density on antioxidation capability in neonatal calves are shown in Table 6 . The plasma T-AOC of neonatal calves was greatly decreased in the $\mathrm{L}$ group compared with that of the $\mathrm{H}$ group $(P$ $<0.01)$. Concentrations of SOD in the $\mathrm{L}$ and M groups were lower $(P<0.05)$ than that in the $\mathrm{H}$ group $(P<$ $0.05)$, whereas plasma GSH-Px and MDA of calves in the L group were increased significantly compared with

Table 3. Effects of prepartum maternal energy density on birth weight and measurements in neonatal calves

\begin{tabular}{lccc}
\hline & \multicolumn{3}{c}{ Group $^{1}$} \\
\cline { 2 - 4 } Item & $\mathrm{H}(\mathrm{n}=10)$ & $\mathrm{M}(\mathrm{n}=10)$ & $\mathrm{L}(\mathrm{n}=10)$ \\
\hline Birth weight, $\mathrm{kg}$ & $43.90 \pm 3.62^{\mathrm{c}}$ & $42.05 \pm 3.52^{\mathrm{cd}}$ & $39.15 \pm 3.42^{\mathrm{d}}$ \\
Body height, $\mathrm{cm}$ & $78.00 \pm 1.83^{\mathrm{ac}}$ & $76.60 \pm 1.43^{\mathrm{acd}}$ & $74.70 \pm 1.64^{\mathrm{bd}}$ \\
Body length, cm & $74.20 \pm 1.69^{\mathrm{a}}$ & $73.60 \pm 1.65^{\mathrm{ab}}$ & $72.56 \pm 1.13^{\mathrm{b}}$ \\
Thoracic girth, $\mathrm{cm}$ & $78.90 \pm 1.60^{\mathrm{c}}$ & $78.00 \pm 1.83^{\mathrm{cd}}$ & $76.61 \pm 1.73^{\mathrm{d}}$ \\
Umbilical girth, $\mathrm{cm}$ & $79.00 \pm 2.05^{\mathrm{a}}$ & $78.10 \pm 2.13^{\mathrm{ab}}$ & $76.67 \pm 2.24^{\mathrm{b}}$ \\
\hline
\end{tabular}

${ }^{\mathrm{a}-\mathrm{d}}$ Means in the same row without a common superscript differ (a,b: $\left.P>0.05 ; \mathrm{c}, \mathrm{d}: P<0.01\right)$. Means in rows with common superscripts do not differ $(P>0.05)$.

${ }^{1} \mathrm{~L}=$ low energy $\left(\mathrm{NE}_{\mathrm{L}}=5.25 \mathrm{MJ} / \mathrm{kg}\right.$ of $\left.\mathrm{DM}\right) ; \mathrm{M}=$ medium energy $\left(\mathrm{NE}_{\mathrm{L}}=5.88 \mathrm{MJ} / \mathrm{kg}\right.$ of $\left.\mathrm{DM}\right) ; \mathrm{H}=$ high energy $\left(\mathrm{NE}_{\mathrm{L}}=6.48 \mathrm{MJ} / \mathrm{kg}\right.$ of $\left.\mathrm{DM}\right)$. 
Table 4. Effects of prepartum maternal energy density on the expression of CD4, CD8, and CD21, and CD4:CD8 ratio in lymphocytes of neonatal calves

\begin{tabular}{lccc}
\hline & \multicolumn{3}{c}{ Group $^{1}$} \\
\cline { 2 - 4 } Item & $\mathrm{H}(\mathrm{n}=10)$ & $\mathrm{M}(\mathrm{n}=10)$ & $\mathrm{L}(\mathrm{n}=10)$ \\
\hline $\mathrm{CD} 4, \%$ & $14.21 \pm 5.48^{\mathrm{ac}}$ & $8.92 \pm 2.43^{\mathrm{bcd}}$ & $5.39 \pm 2.07^{\mathrm{bd}}$ \\
CD8, \% & $9.91 \pm 3.34^{\mathrm{a}}$ & $10.98 \pm 2.53^{\mathrm{a}}$ & $11.45 \pm 3.85^{\mathrm{a}}$ \\
CD21, \% & $9.87 \pm 3.58^{\mathrm{a}}$ & $10.63 \pm 4.27^{\mathrm{a}}$ & $10.26 \pm 3.14^{\mathrm{a}}$ \\
CD4:CD8 & $1.30 \pm 0.54^{\mathrm{a}}$ & $0.77 \pm 0.25^{\mathrm{bcd}}$ & $0.61 \pm 0.11^{\mathrm{bd}}$ \\
\hline
\end{tabular}

${ }^{\mathrm{a}-\mathrm{d}}$ Means in the same row without a common superscript differ (a,b: $\left.P>0.05 ; \mathrm{c}, \mathrm{d}: P<0.01\right)$. Means in rows with common superscripts do not differ $(P>0.05)$.

${ }^{1} \mathrm{~L}=$ low energy $\left(\mathrm{NE}_{\mathrm{L}}=5.25 \mathrm{MJ} / \mathrm{kg}\right.$ of $\left.\mathrm{DM}\right) ; \mathrm{M}=$ medium energy $\left(\mathrm{NE}_{\mathrm{L}}=5.88 \mathrm{MJ} / \mathrm{kg}\right.$ of $\left.\mathrm{DM}\right) ; \mathrm{H}=$ high energy $\left(\mathrm{NE}_{\mathrm{L}}=6.48 \mathrm{MJ} / \mathrm{kg}\right.$ of $\left.\mathrm{DM}\right)$.

those in the $\mathrm{H}$ group $(P<0.05)$. Consequently, the antioxidation capabilities of neonatal calves were altered by maternal energy density in the last $21 \mathrm{~d}$ of gestation.

\section{DISCUSSION}

Fetal growth and development depends upon the acquisition of maternal digested or metabolic products, which can promote fetal growth directly by providing essential chemical elements for fetal tissue growth (Gao et al., 2007). Inadequate maternal nutrition or low energy during pregnancy influences the fetal growth trajectory (Robinson et al., 1999; McMillen et al., 2001) because partitioning of fetal substrates is disturbed or destroyed by changes of maternal metabolic status (Gao et al., 2007), which would compromise postnatal growth, metabolism, and health (Gao et al., 2006, 2009; Micke et al., 2010). In this study, although maternal weight was not affected by energy density in the last $21 \mathrm{~d}$ of gestation, concentrations of Glu, NEFA, and BHBA in dairy cows was altered, which might reprogram the supply of nutrients and physiological regulation from cow to fetus and lead to the significant reduction in birth weight, body height, body length, thoracic girth, and umbilical girth of neonatal calves.

The $\mathrm{CD}^{+}$and $\mathrm{CD} 8^{+} \mathrm{T}$ cells are 2 important subsets of $\mathrm{T}$ lymphocytes. The ratio of $\mathrm{CD} 4^{+}$to $\mathrm{CD} 8^{+}$varies with health and disease status, and is highly relevant to the immune capability of individuals (Lu et al., 2011). The $\mathrm{CD}^{+} \mathrm{T}$ cells, mainly T-helper (Th) 1 and Th2 cells, play a central role in immune protection and are responsible for activating and directing other immune cells (Zhu and William, 2008). The Th1 cells produce IL-2, which is essential for T-cell proliferation and functions as a T-cell growth factor (Miyawaki et al., 1987), whereas Th2 cells produce IL-4 and IL-6 (Bloom et al., 1992). As an important factor in the clonal expansion of antigen-specific B cells, IL-4 enhances the synthesis of IgE (Coffman and Carty, 1986; Kuhn et al., 1991),
IgG1 (Coffman et al., 1986), and IgG4 (Lundgren et al., 1989) and induces proliferation and differentiation of B cells (Gemmell and Seymour, 1994). Interleukin-6 activates $\mathrm{T}$ and $\mathrm{B}$ cells and plays a role in mediation of inflammation and immune responses initiated by infection and injury (Van Snick, 1990). In this study, the percentage of $\mathrm{CD}^{+} \mathrm{T}$ lymphocytes and the $\mathrm{CD} 4^{+}: \mathrm{CD} 8^{+}$ratio in neonatal calves of $\mathrm{L}$ group were significantly decreased $(P<0.01)$ compared with the $\mathrm{H}$ group during the last $3 \mathrm{wk}$ of gestation, which implied that the immune capability of neonatal calves might be influenced by the decrease in prepartum energy density. Furthermore, the decreased $\mathrm{CD}^{+} \mathrm{T}$ lymphocytes in neonatal calves of the L group might have contributed to the reduced production of IL-2 and IL-4. In turn, the reduction in IL-2 might further suppress $\mathrm{CD} 4^{+}$T-cell division. The expression of CD21 (a key marker for activation of $\mathrm{B}$ lymphocytes) and the concentration of IL-6 that activates $\mathrm{T}$ and B cells did not differ among $\mathrm{L}, \mathrm{M}$, and $\mathrm{H}$ group $(P>0.05)$, which indicated that the activation of $\mathrm{B}$ cells of neonatal calves in each group might be not affected by prepartum energy density. The concentration of IL-4, however, was significantly reduced $(P<0.01)$ in $\mathrm{L}$ group calves, which might change the synthesis of immunoglobulins. The development of immunocompetence in L group calves was reduced during the last $21 \mathrm{~d}$ of gestation. Gao et al. (2006) indicated that CD21 expression of B lymphocytes was not changed but CD3 expression of $\mathrm{T}$ lymphocytes was decreased $(P<0.05)$ in neonatal lambs because of maternal undernutrition during late pregnancy, which was in agreement with our results.

Oxidative stress occurs as a consequence of imbalance between natural cellular antioxidative defenses and the prooxidant state, culminating in the production of potentially destructive reactive oxygen species (ROS), and leading to alterations in cellular membrane structures (Abd Hamid et al., 2011), changes in enzymatic activity such as SOD, GSH-Px, and catalase (Georgieva et 
A

lgG2a-FITC

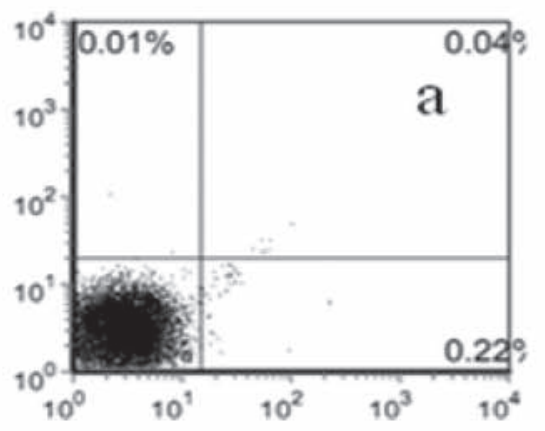

$\lg \mathrm{G} 2 \mathrm{a}-\mathrm{PE}$

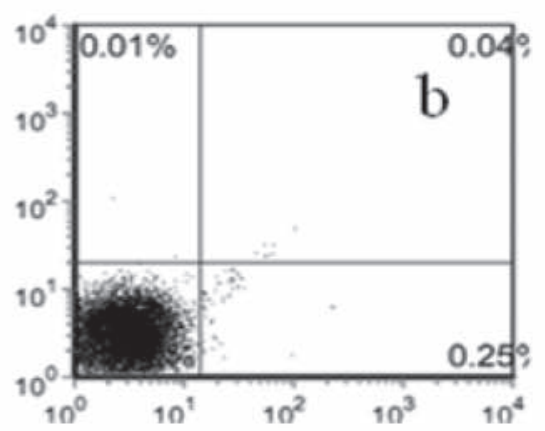

lgG1-FITC

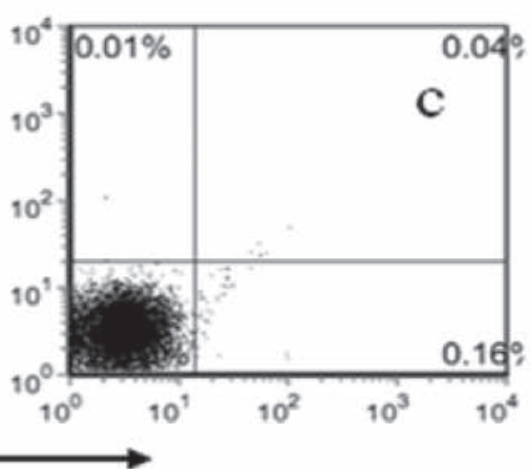

B

$\mathrm{H}$ group

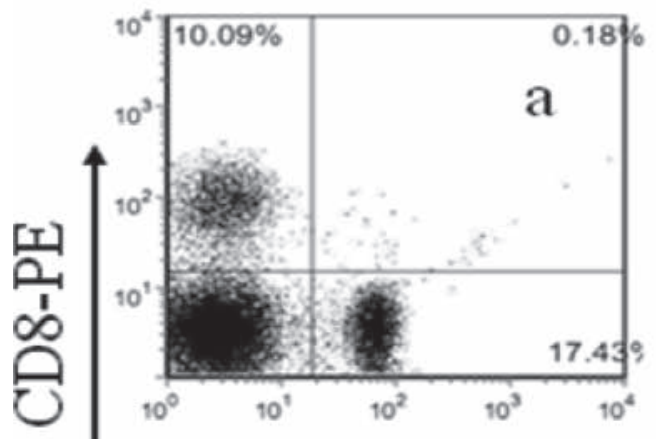

M group

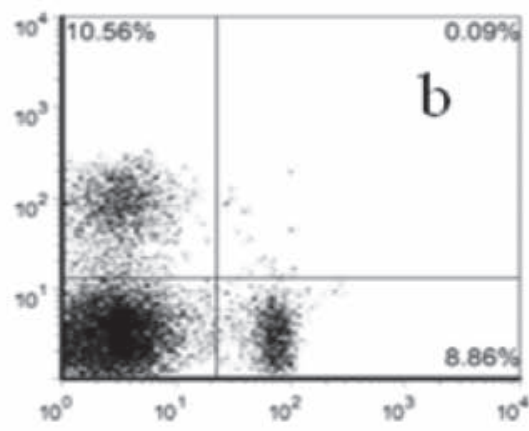

L group

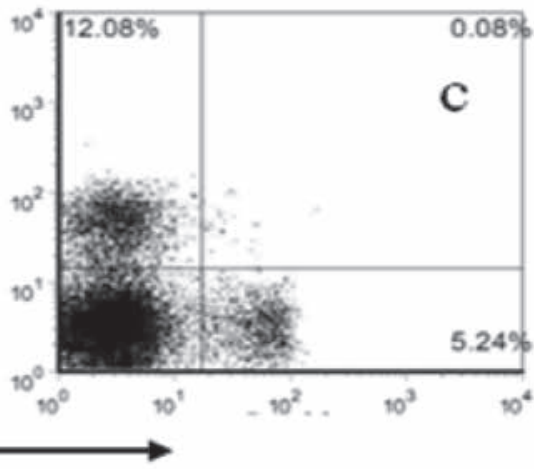

CD4-FITC

C H group

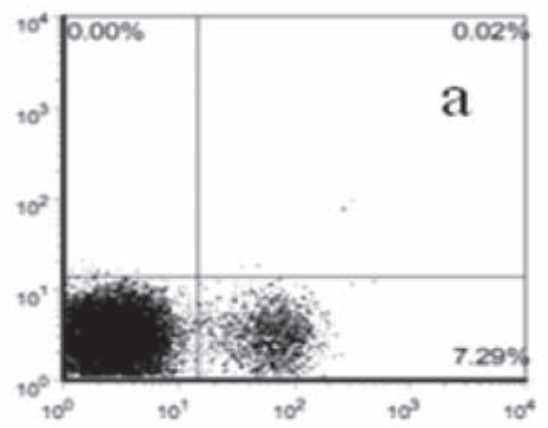

M group

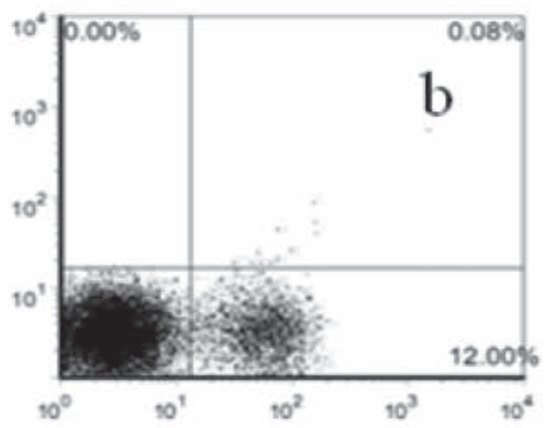

L group

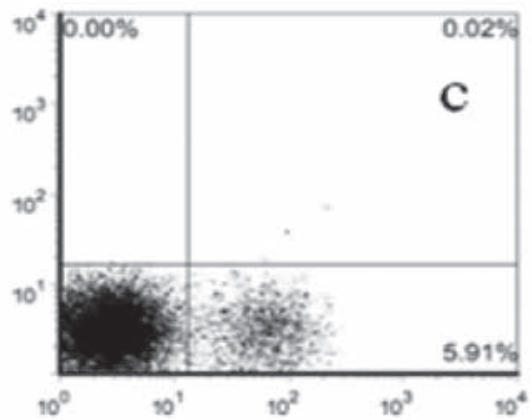

\section{CD21-FITC}

Figure 1. Effects of prepartum maternal energy density on the expression of CD4, CD8, CD21, and CD4:CD8 in neonatal calf blood. (A) Lymphocytes stained with (a) IgG2a-fluorescein isothiocyanate (FITC), (b) IgG2a-phycoerythrin (PE), and (c) IgG1-FITC by flow cytometry as isotype control. (B) Representative flow cytometry profile showing cells stained with FITC-conjugated mouse anti-bovine CD4 monoclonal antibodies (mAb), PE-conjugated mouse anti-bovine CD8 mAb in $\mathrm{H}$ (a), M (b), and L (c) groups, respectively. (C) Representative flow cytometry profile showing cells stained with FITC-conjugated mouse anti-bovine CD21 mAb in H (a), M (b), and L (c) groups, respectively. Ten neonatal calves in each group were examined. $\mathrm{L}=$ low energy diet prepartum $\left(\mathrm{NE}_{\mathrm{L}}=5.25 \mathrm{MJ} / \mathrm{kg}\right.$ of $\left.\mathrm{DM}\right) ; \mathrm{M}=$ medium energy $\left(\mathrm{NE} \mathrm{L}_{\mathrm{L}}=5.88 \mathrm{MJ} / \mathrm{kg}\right.$ of $\mathrm{DM}) ; \mathrm{H}=$ high energy $\left(\mathrm{NE}_{\mathrm{L}}=6.48 \mathrm{MJ} / \mathrm{kg}\right.$ of $\left.\mathrm{DM}\right)$. 
Table 5. Effects of prepartum maternal energy density on plasma IL-2, IL-4, and IL-6 concentrations in neonatal calves

\begin{tabular}{|c|c|c|c|}
\hline \multirow[b]{2}{*}{ Item } & \multicolumn{3}{|c|}{ Group $^{1}$} \\
\hline & $\mathrm{H}(\mathrm{n}=10)$ & $\mathrm{M}(\mathrm{n}=10)$ & $\mathrm{L}(\mathrm{n}=10)$ \\
\hline $\begin{array}{l}\text { IL-2, ng/mL } \\
\text { IL-4, ng/mL } \\
\text { IL-6, pg/mL }\end{array}$ & $\begin{aligned} 6.46 & \pm 2.38^{\mathrm{a}} \\
1.20 & \pm 0.39^{\mathrm{ac}} \\
248.93 & \pm 72.00^{\mathrm{a}}\end{aligned}$ & $\begin{aligned} 5.23 & \pm 1.00^{\mathrm{ab}} \\
0.81 & \pm 0.27^{\mathrm{bcd}} \\
202.18 & \pm 51.20^{\mathrm{a}}\end{aligned}$ & $\begin{aligned} 4.47 & \pm 1.81^{\mathrm{b}} \\
0.77 & \pm 0.07^{\mathrm{bd}} \\
233.64 & \pm 65.47^{\mathrm{a}}\end{aligned}$ \\
\hline
\end{tabular}

al., 2011), and ultimately cell death (Pham-Huy et al., 2008). As an antioxidant enzyme, SOD promotes the conversion of an anion superoxide to $\mathrm{H}_{2} \mathrm{O}_{2}$ (Al-Gubory et al., 2010), and GSH-Px prevents free radical damage to phospholipid membranes, enzymes, and other important molecules (Mruk et al., 2002). Recent experimental studies have documented that changes in nutrition levels could lower the activities of SOD and GSH-Px (Wang et al., 2011), disrupt the balance of ROS (Sies et al., 2005), increase the level of MDA (Bai and Jones., 1996), and reduce antioxidation capability (Ziegler et al., 1995). Maleic dialdehyde, as one of the metabolic products of lipid peroxides (Zhan et al., 2007), is an indicator of ROS-induced oxidative stress. In the present study, although the concentration of GSH-Px $(P<$ $0.05)$ increased in the $\mathrm{L}$ group, the higher concentration of MDA $(P<0.05)$ in calves of the $\mathrm{L}$ group indicated that oxidative stress was generated in those calves. The lower SOD might be responsible for the reduction of $\mathrm{T}$-AOC in the L group, which might further explain the occurrence of oxidative stress in the $\mathrm{L}$ group due to a disturbance of the antioxidant-prooxidant equilibrium. Therefore, the antioxidation capability of neonatal calves could be significantly affected by the energy plane of cows during the last 3 wk of gestation, which might impair the health of neonatal calves.

\section{CONCLUSIONS}

In this study, low maternal energy density in the last $21 \mathrm{~d}$ of pregnancy resulted in decreased calf birth weight, body height, body length, thoracic girth, and umbilical girth, as well as decreased expression of CD4 and CD4:CD8, decreased concentrations of IL-2, IL4, T-AOC, and SOD, and increased concentration of MDA compared with cows with high prepartum energy density. The changes were induced by modification of the metabolic responses of transition dairy cows, which demonstrated that growth performance, immunity, and antioxidation of neonatal calves were largely affected by maternal energy density during the last $21 \mathrm{~d}$ of gestation. High maternal energy density at 3 wk prepartum might improve the postnatal growth and health of calves.

\section{ACKNOWLEDGMENTS}

This work was supported by grants from Scientific Research Program of State Key Laboratory of Animal Nutrition (2004DA125184F1009). The authors gratefully acknowledge Yong Zhao and HongRan Li from State Key Laboratory of Biomembrane and Membrane

Table 6. Effects of prepartum maternal energy density on the antioxidation capability in neonatal calves

\begin{tabular}{|c|c|c|c|}
\hline \multirow[b]{2}{*}{ Item $^{1}$} & \multicolumn{3}{|c|}{ Group $^{2}$} \\
\hline & $\mathrm{H}(\mathrm{n}=10)$ & $\mathrm{M}(\mathrm{n}=10)$ & $\mathrm{L}(\mathrm{n}=10)$ \\
\hline $\begin{array}{l}\text { T-AOC, U/mL } \\
\text { SOD, U/mL } \\
\text { GSH-Px, U/mL } \\
\text { MDA, nmol/mL }\end{array}$ & $\begin{array}{r}0.56 \pm 0.19^{\mathrm{c}} \\
123.45 \pm 7.89^{\mathrm{a}} \\
2.76 \pm 0.74^{\mathrm{b}} \\
2.37 \pm 0.78^{\mathrm{b}}\end{array}$ & $\begin{aligned} 0.40 & \pm 0.18^{\mathrm{cd}} \\
114.94 & \pm 6.53^{\mathrm{b}} \\
3.50 & \pm 1.20^{\mathrm{ab}} \\
3.00 & \pm 1.22^{\mathrm{ab}}\end{aligned}$ & $\begin{array}{r}0.26 \pm 0.10^{\mathrm{d}} \\
114.83 \pm 5.60^{\mathrm{b}} \\
4.35 \pm 1.34^{\mathrm{a}} \\
3.43 \pm 0.39^{\mathrm{a}}\end{array}$ \\
\hline \multicolumn{4}{|c|}{$\begin{array}{l}{ }^{\mathrm{a}-\mathrm{d}} \text { Means in the same row without a common superscript differ }(\mathrm{a}, \mathrm{b}: P>0.05 ; \mathrm{c}, \mathrm{d}: P<0.01) \text {. Means in rows } \\
\text { with common superscripts do not differ }(P>0.05) \text {. } \\
{ }^{1} \mathrm{~T}-\mathrm{AOC}=\text { total antioxidant capacity; } \mathrm{SOD}=\text { superoxide dismutase; GSH-Px }=\text { glutathione peroxidase; MDA } \\
=\text { maleic dialdehyde. } \\
{ }^{2} \mathrm{~L}=\text { low energy }\left(\mathrm{NE}_{\mathrm{L}}=5.25 \mathrm{MJ} / \mathrm{kg} \text { of } \mathrm{DM}\right) ; \mathrm{M}=\text { medium energy }\left(\mathrm{NE}_{\mathrm{L}}=5.88 \mathrm{MJ} / \mathrm{kg} \text { of } \mathrm{DM}\right) ; \mathrm{H}=\text { high } \\
\text { energy }\left(\mathrm{NE}_{\mathrm{L}}=6.48 \mathrm{MJ} / \mathrm{kg} \text { of } \mathrm{DM}\right) .\end{array}$} \\
\hline
\end{tabular}


Biotechnology of Institute of Zoology in Chinese Academy of Sciences for their expert technical assistance.

\section{REFERENCES}

Abd Hamid, N. A., M. A. Hasrul, and R. J. Ruzanna. 2011. Effect of vitamin $\mathrm{E}$ on antioxidant enzymes and DNA damage in rats following eight weeks exercise. Nutr. J. 10:37-38.

Al-Gubory, K. H., C. Garrel, L. Delatouche, Y. Heyman, and P. Chavatte-Palmer. 2010. Antioxidant adaptive responses of extraembryonic tissues from cloned and non-cloned bovine conceptuses to oxidative stress during early pregnancy. Reproduction 140:175181.

Bai, C., and D. P. Jones. 1996. GSH transport, and GSH dependent detoxication in small intestine of rats exposed in vivo to hypoxia. Am. J. Physiol. 271:G701-706.

Bateman, H. G., A. E. Beem, C. C. Stanley, C. C. Williams, and C. F. Hutchison. 2005. Case study: Using urine $\mathrm{pH}$ as a predictor for ketosis in transition dairy cows. Prof. Anim. Sci. 21:515-520.

Bloom, B. R., P. Salgame, and B. Diamond. 1992. Revisiting and revising suppressor T cells. Immunol. Today 13:131-136.

Coffman, R. L., and J. Carty. 1986. A T cell activity that enhances polyclonal IgE production and its inhibition by interferon-gamma. J. Immunol. 136:949-954.

Coffman, R. L., J. Ohara, M. W. Bond, J. Carty, A. Zlotnik, and W. E. Paul. 1986. B cell stimulatory factor-I enhances the IgE response of lipopolysaccharide-activated B cells. J. Immunol. 136:4538-4541.

Contreras, L. L., C. M. Ryan, and T. R. Overton. 2004. Effects of dry cow grouping strategy and prepartum body condition score performance and health of transition dairy cows. J. Dairy Sci. $87: 517-523$.

Dewhurst, R. J., J. M. Moorby, M. S. Dhanoa, R. T. Evans, and W. J. Fisher. 2000. Effects of altering energy and protein supply to dairy cows during the dry period. 1. Intake, body condition and milk production. J. Dairy Sci. 83:1782-1794.

Douglas, G. N., J. K. Drackley, T. R. Overton, and H. G. Bateman. 1998. Lipid metabolism and production by Holstein cow fed control or high fat diets at restricted or ad libitum in takes during the dry period. J. Dairy Sci. 81:295-301.

Drackley, J. K. 1999. Biology of dairy cows during the transition period: The final frontier? J. Dairy Sci. 82:2259-2273.

Ferguson, J. D. 2001. Nutrition and reproduction in dairy herds. Pages 65-82 in Proc. Intermountain Nutr. Conf., Salt Lake City, UT. Utah State Univ., Logan.

Gaafar, H. M. A., S. M. Shamiah, M. A. A. El-Hamd, A. A. Shitta, and M. A. T. El-Din. 2011. Dystocia in Friesian cows and its effects on postpartum reproductive performance and milk production. Trop. Anim. Health Prod. 43:229-234.

Gao, F., X. Z. Hou, Y. C. Liu, S. Q. Wu, and C. J. Ao. 2008. Effect of maternal under nutrition during late pregnancy on lambs birth weight. Asian-australas. J. Anim. Sci. 21:371-375.

Gao, F., X. Z. Hou, S. Q. Wu, and C. J. Ao. 2006. Effect of different undernutrition received by ewes at late pregnancy on utilization and mobilization of adipose tissue. J. Livest. China 42:36-40.

Gao, F., Y. X. Z. Hou, and Y. C. Liu. 2007. Effect of maternal undernutrition during late pregnancy on blood biochemical parameters and fetal growth development. Sci. China C Life Sci. 37:562-567.

Gao, F., Y. C. Liu, and X. Z. Hou. 2009. Effect of maternal undernutrition during late pregnancy on growth and development of ovine fetal visceral organs. Asian-australas. J. Anim. Sci. 22:1633-1639.

Gemmell, E., and G. J. Seymour. 1994. Cytokines and T cell switching. Crit. Rev. Oral Biol. Med. 5:249-279.

Georgieva, N. V., M. Gabrashanska, K. Ventsislav, and Z. Yaneva. 2011. Zinc supplementation against Eimeria acervulina induced oxidative damage in broiler chickens. Vet. Med. Int. 2011:647124.

Ghavi Hossein-Zadeh, N., and M. Ardalan. 2011. Cow-specific risk factors for retained placenta, metritis and clinical mastitis in Holstein cows. Vet. Res. Commun. 35:345-354.
Grétar, H. H. 2001. Is the modern high potential dairy cow suitable for organic farming conditions? Acta Vet. Scand. 95:63-67.

Hayirli, A. R., R. Grummer, E. V. Nordheim, and P. M. Crump. 2002. Animal and dietary factors affecting feed intake during the prefresh transition period in Holsteins. J. Dairy Sci. 85:3430-3443.

Holcomb, C. S., H. H. Van Horm, H. H. Head, M. B. Hall, and C. J. Willox. 2001. Effect of prepartum dry matter intake and forage percentage on postpartum performance of lactating dairy cow. J. Dairy Sci. 84:2051-2058.

Houe, H., S. Ostergaard, T. Thilsing-Hansen, R. J. Jorgensen, T. Larsen, J. T. Sorensen, J. F. Agger, and J. Y. Blom. 2001. Milk fever and subclinical hypocalcaemia - An evaluation of parameters on incidence risk, diagnosis, risk factors and biological effects as input for a decision support system for disease control. Acta Vet. Scand. 42:1-29.

Ingvartsen, K. L. 2006. Feeding and management-related diseases in the transition cow: Physiological adaptations around calving and strategies to reduce feeding-related diseases. Anim. Feed Sci. Technol. 126:175-213.

Ingvartsen, K. L., and J. B. Andersen. 2000. Integrtion of metabolism and intake regulation: A review focusing on periparturient animals. J. Dairy Sci. 83:1573-1597.

Kimura, K., T. A. Reinhardt, and J. P. Goff. 2006. Parturition and hypocalcaemia blunts calcium signals and immune cells of dairy cattle. J. Dairy Sci. 89:2588-2595.

Kühn, R., K. Rajewsky, and W. Muller. 1991. Generation analysis of interleukin-4 deficient mice. Science 254:707-710.

Louey, S., M. L. Cock, K. M. Stevenson, and R. Harding. 2000. Placental insufficiency and fetal growth restriction lead to postnatal hypotension and altered postnatal growth in sheep. Pediatr. Res. $48: 808-814$.

Lu, X., J. F. Liu, Y. F. Gong, Z. P. Wang, Y. Liu, and Q. Zhang. 2011. Mapping quantitative trait loci for T lymphocyte subpopulations in peripheral blood in swine. BMC Genet. 12:79-88.

Lundgren, M., U. Persson, P. Larsson, C. Magnusson, C. I. E. Smith, L. Hammarström, and E. Severinson. 1989. Interleukin 4 induces synthesis of IgE and IgG4 in human B cells. Eur. J. Immunol. 19:1311-1315.

McMillen, I. C., M. B. Adams, J. T. Ross, C. L. Coulter, G. Simonetta, J. A. Owens, J. S. Robinson, and L. J. Edwards. 2001. Fetal growth restriction: Adaptations and consequences. Reproduction 122:195-204.

Micke, G. C., T. M. Sullivan, R. J. Soares Magalhaes, P. J. Rolls, S. T. Norman, and V. E. A. Perry. 2010. Heifer nutrition during earlyand mid-pregnancy alters fetal growth trajectory and birth weight. Anim. Reprod. Sci. 117:1-10.

Miyawaki, T., T. Suzuki, J. L. Butler, and M. D. Cooper. 1987. Interleukin-2 effects on human B cells activated in vivo. J. Clin. Immunol. 7:277-287.

Mruk, D. D., B. Silvestrini, M. Y. Mo, and C. Y. Cheng. 2002. Antioxidant superoxide dismutase - A review: Its function, regulation in the testis, and role in male fertility. Contraception 65:305-311.

Mulligan, F., L. O. Grady, D. Rice, and M. Doherty. 2006. Production diseases of the transition cow: Milk fever and subclinical hypocalcaemia. J. Irish Vet. 59:697-702.

NRC. 2001. Nutrient Requirements of Dairy Cattle. 7th rev. ed. National Academy Press, Washington, DC.

Osgerby, J. C., D. C. Wathes, D. Howard, and T. S. Gadd. 2002. The effect of maternal undernutrition on ovine fetal growth. J. Endocrinol. 173:131-141.

Paglia, D. E., and W. N. Valentine. 1967. Studies on the quantitative and qualitative characterization of erythrocytes glutathione peroxidase. J. Lab. Clin. Med. 70:158-169.

Panchenko, L. F., O. S. Brusov, A. M. Gerasimov, and A. E. Loktaeva. 1975. Intramitochondrial localization and release of rat liver superoxide dismutase. FEBS Lett. 55:84-87.

Pham-Huy, L. I., H. He, and C. Pham-Huy. 2008. Free radicals, antioxidants in disease and health. Int. J. Biomed. Sci. 4:89-96.

Placer, Z. A., L. L. Cushman, and B. C. Johnson. 1966. Estimation of product of lipid peroxidation (malondialdehyde) in biochemical systems. Anal. Biochem. 16:359-364. 
Quigley, S. P., D. O. Kleemann, S. K. Walker, P. A. Speck, S. R. Rudiger, G. S. Nattrass, M. J. De Blasio, and J. A. Owens. 2008. Effect of variable long-term maternal feed allowance on the development of the ovine placenta and fetus. Placenta 29:539-548.

Rabelo, E. R., R. L. Rezende, S. J. Bertics, and R. R. Grummer. 2003 Effects of transition diets varying in dietary energy density on lactation performance and ruminal parameters of dairy cows. J. Dairy Sci. 86:916-925.

Redmer, D. A., J. M. Wallace, and L. P. Reynolds. 2004. Effect of nutrient intake during pregnancy on fetal and placental growth and vascular development. Domest. Anim. Endocrinol. 27:199-217.

Reynolds, C. K., B. Durst, B. Lupoli, D. J. Humphries, and D. E. Beever. 2004. Visceral tissue mass and rumen volume in dairy cows during the transition from late gestation to early lactation. J. Dairy Sci. 87:961-971.

Robinson, J. J., K. D. Sinclair, and T. G. McEvoy. 1999. Nutritional effects on foetal growth. Anim. Sci. 68:315-331.

Sies, H., W. Stahl, and A. Sevanian. 2005. Nutritional, dietary and postprandial oxidative stress. J. Nutr. 135:969-972.

Van Snick, J. 1990. Interleukin-6: An overview. Annu. Rev. Immunol. 8:253-278.

Van Winden, S. C., C. R. Brattinga, K. E. Muller, J. P. Noordhuizen, and A. C. Beynen. 2002. Position of the abomasum in dairy cows during the first six weeks after calving. Vet. Rec. 151:446-449.

Vandehaar, M. J., G. Yousif, B. K. Sharma, T. H. Herdt, R. S. Emery, M. S. Allen, and J. S. Liesman. 1999. Effect of energy and protein density of prepartum diets on fat and protein metabolism of dairy cattle in the periparturient period. J. Dairy Sci. 82:1282-1295.

Wang, Y. X., X. A. Zhan, X. W. Zhang, R. J. Wu, and D. Yuan. 2011. Comparison of different forms of dietary selenium supplementation on growth performance, meat quality, selenium deposition, and antioxidant property in broilers. Biol. Trace Elem. Res. $143: 261-273$.

Zhan, X. A., M. Wang, R. Q. Zhao, W. F. Li, and Z. R. Xu. 2007. Effects of different selenium source on selenium distribution, loin quality and antioxidant status in finishing pigs. Anim. Feed Sci. Technol. 132:202-211.

Zhang, R., Q. Y. Diao, N. F. Zhang, Y. Tu, and C. G. Jiang. 2010 Effects of different energy levels on nutrient utilization and serum biochemical parameters of early-weaned calves. Agric. Sci. China 9:729-735.

Zhu, J. F., and E. P. William. 2008. CD4 T cells: Fates, functions, and faults. Blood 112:1557-1569.

Zhu, M. J., M. Du, B. W. Hess, W. J. Means, P. W. Nathanielsz, and S. P. Ford. 2007. Maternal nutrient restriction upregulates growth signalling pathways in the cotyledonary artery of cow placentomes. Placenta 28:361-368.

Ziegler, T. R.. A. Almahfouz, M. T. Pedrini, and R. J. Smith. 1995 A comparison of rat small intestine insulin and insulin like growth factor I receptors during fasting and refeeding. J. Endocrinol. 136:5148-5154. 